\title{
Potato Late Blight Management in the Toluca Valley: Field Validation of SimCast Modified for Cultivars with High Field Resistance
}

\author{
Niklaus J. Grünwald, United States Department of Agriculture-Agricultural Research Service (USDA-ARS), \\ Prosser, WA 99350; Gaspar Romero Montes and H. Lozoya Saldaña, Cornell-Eastern Europe-Mexico and Pro- \\ grama Internacional Cooperativo del Tizón Tardío de la Papa (CEEM/PICTIPAPA) Potato Late Blight Project, \\ Cuauhtemoc Izcalli V, Metepec, Edo. de México 52176, México; O. A. Rubio Covarrubias, Instituto Nacional de \\ Investigaciones Forestales, Agrícolas y Pecuarias (INIFAP), Conjunto Sedagro, Metepec, Edo. de México 52142, \\ México; and William E. Fry, Department of Plant Pathology, Cornell University, Ithaca, NY 14853
}

\begin{abstract}
Grünwald, N. J., Romero Montes, G., Lozoya Saldaña, H., Rubio Covarrubias, O. A., and Fry, W. E. 2002. Potato late blight management in the Toluca valley: Field validation of SimCast modified for cultivars with high field resistance. Plant Dis. 86:1163-1168.

Management of potato late blight in the highland tropics is very costly and remains difficult. Reducing the impact of late blight through the use of resistant cultivars in combination with a fungicide forecasting system could lower the number of costly fungicide applications. Previously, we evaluated the fungicide advisory SimCast for use with Mexican cultivars of high levels of field resistance for use in the central highlands of Mexico and found that it predicted too many fungicide applications for cultivars of moderate to high levels of resistance. We adapted SimCast for cultivars with higher levels of resistance, and field validations conducted in 1999 and 2000 show that SimCast resulted in good disease control on cultivars ranging from susceptible to highly resistant. The number of fungicide applications forecast for cultivars with moderate to high levels of resistance was reduced. Precipitation was the environmental variable responsible for most of the forecasts made. Our work demonstrates that a predictive system can be portable from the temperate climate to a tropical highland climate. A user-friendly decision support system consisting of just a rain-gauge and the exclusive use of SimCast's fungicide units could be a valuable and affordable tool in managing potato late blight in the highland tropics.
\end{abstract}

Additional keywords: epidemiology, plant pathogen, yield loss

Management of potato late blight in the highland tropics is very costly and remains difficult. Although, in the developed world, control of potato late blight relies heavily on the use of fungicides, growers in the developing world often cannot control the disease due to lack of resources, which results in heavy losses and at times crop abandonment $(6,7,11-13,17)$. Two technologies most suitable for management of late blight for resource-poor farmers are the use of cultivars with high levels of resistance and the use of generic, low-cost

Corresponding author: N. J. Grünwald E-mail: ngrunwald@pars.ars.usda.gov

Major funding for this work was provided by PICTIPAPA (Programa Internacional Cooperativo del Tizón Tardío de la Papa) and the CEEM (Cornell-Eastern Europe-Mexico) Potato Late Blight Project. The work also was supported by USDA CRIS project 5354-21220-009-00.

Accepted for publication 3 June 2002.

Publication no. D-2002-0819-02R

This article is in the public domain and not copyrightable. It may be freely reprinted with customary crediting of the source. The American Phytopathological Society, 2002. fungicides such as mancozeb. Fungicide use can be optimized by adapting fungicide management to local weather conditions and to cultivar resistance through the use of a disease forecasting system.

Use of cultivars resistant to potato late blight is the most economical means of controlling potato late blight, particularly for resource-poor growers. Cultivars with high levels of resistance to late blight have been developed by the Mexican National Potato program $(2,3,9,11,15)$. Some of these cultivars can be grown with just a few fungicide applications, but often it is not clear how many applications are necessary $(9,11)$. The cultivars were developed in the Toluca valley and have always been exposed to a sexual population diverse in races $(8,10,14,16)$.

Integration of resistance with fungicide management schemes can improve disease management while simultaneously lowering costs. Previous work had established that SimCast, a fungicide forecasting system developed for temperate climates (5), resulted in good disease control under Toluca valley conditions, but recommended too many fungicide applications with resistant or highly resistant potato cultivars (11). A modeling effort using historical weather data and disease data as well as separate experiments with cultivars differing in levels of resistance $(\mathrm{N}$. J. Grünwald, unpublished) established that SimCast could be adapted to give justice to cultivars with higher levels of resistance.

Our objective was to adapt SimCast for use with Mexican cultivars of high levels of field resistance for use in the central highlands of Mexico and to subsequently validate the modified version of SimCast in field trials in the Toluca Valley. We tested the hypothesis that the modified SimCast would result in disease control corresponding to scheduled fungicide applications while reducing fungicide usage in cultivars with moderate to high levels of field resistance.

\section{MATERIALS AND METHODS}

Modification of SimCast. Previous work (11) established that SimCast resulted in too many spray advisories with cultivars resistant to highly resistant to potato late blight and needed to be adapted for local conditions. Historic weather data obtained between 1997 and 1998 (11) were used to modify SimCast (5) with the objective of reducing the number of sprays forecast for cultivars that were resistant or highly resistant to late blight. Spreadsheets with daily weather data including (i) average temperature during hours of high relative humidity ( $\mathrm{RH} \geq 90 \%$ ), (ii) number of hours of high RH, and (iii) precipitation (in millimeters) were prepared for simulations. Several iterations of different combinations of minor and major modifications were evaluated for numbers of sprays recommended for the season. The objective was to reduce the number of sprays for resistant cultivars to 5 to 6 and for highly resistant cultivars to 3 to 5 sprays per season when simulated for Toluca Valley conditions.

Cultural procedures. Field experiments were conducted at the Instituto Nacional de Investigaciones Forestales, Agrícolas y Pecuarias (INIFAP) field station in Metepec, Toluca Valley, in 1999 and 2000. Whole tubers of cvs. Alpha, Rosita, and Norteña were planted on 11 June 1999 and 22 June 2000. Cvs. Rosita and Norteña emerge later and over a longer period and 
mature later than cv. Alpha. A private company provided Alpha seed tubers. Experimental plots were 4 by $3.7 \mathrm{~m}$ wide (4 rows/plot; 16 plants/row). Treatments were randomized in complete blocks with four replications. Plots were separated from each other by $4 \mathrm{~m}$ to avoid interplot interference.

Fertilization and nonexperimental pesticide applications were applied according to standard grower practice. Tubers were treated with benomyl (Benlate; $1 \mathrm{~kg}$ a.i./ha) and Captan (Captan $50 \mathrm{PH} ; 1 \mathrm{~kg}$ a.i./ha) in the planting hole with a hand sprayer. Fertilizer was applied at time of planting ( $\mathrm{N}$ at $120 \mathrm{~kg} / \mathrm{ha} ; \mathrm{P}$ at $180 \mathrm{~kg} / \mathrm{ha} ; \mathrm{K}$ at $120 \mathrm{~kg} / \mathrm{ha}$; $\mathrm{Ca}$ and $\mathrm{Mg}$ at $20 \mathrm{~kg} / \mathrm{ha}$ ) together with the granulated insecticide terbufos (Counter FZ-15; $1.05 \mathrm{~kg}$ a.i./ha). A second fertilizer application (60 kg of $\mathrm{N}$ ) was applied at hilling on 26 to 27 July 1999 and 28 July 2000. The fungicide chlorothalonil (Bravo 720) was applied at a rate of $1.15 \mathrm{~kg}$ a.i./ha with a hand sprayer.
The herbicide metribuzin (Lexone) was applied at a rate of $525 \mathrm{~g}$ a.i./ha when needed. Several insecticides were applied weekly in rotation as needed (methamidophos, dimethoate, oxamyl, monocrotophon, methomyl, and endosulfan).

Fungicide spray advisory. Each cultivar received the two fungicide advisory treatments most appropriate to its level of resistance. Thus, cv. Alpha (AL) was treated as either susceptible or moderately susceptible to late blight. Cv. Rosita (RO) was treated as either moderately resistant or resistant because previous work had established that Rosita ends up in about $20 \%$ final disease severity without fungicide applications (11). Similarly, cv. Norteña (NO) was treated as either resistant or highly resistant (Table 1) because previous work showed that final disease severity without fungicide application resulted in about 5\% disease severity. Each cultivar was also grown in a treatment without fungicide application (0-AL, 0 -

Table 1. Definition of abbreviations for treatments applied to experiments conducted at the Experimental Field Station of the Mexican National Potato Program of INIFAP in the Toluca Valley in 1999 and 2000

\begin{tabular}{llll}
\hline & \multicolumn{2}{c}{ Definition } \\
\cline { 2 - 4 } Abbreviation & Cultivar & \multicolumn{1}{c}{ Fungicide treatment } & \multicolumn{1}{c}{ Description } \\
\hline 0-AL & Alpha & None & No-spray control \\
7d-AL & Alpha & Weekly & Calendar spray \\
SIM-S-AL & Alpha & SimCast: susceptible & Forecast \\
SIM-MS-AL & Alpha & SimCast: moderately susceptible & Forecast \\
0-RO & Rosita & None & No-spray control \\
10d-RO & Rosita & Every 10 days & Calendar spray \\
SIM-MR-RO & Rosita & SimCast: moderately resistant & Forecast \\
SIM-R-RO & Rosita & SimCast: resistant & Forecast \\
0-NO & Norteña & None & No-spray control \\
14d-NO & Norteña & Every 14 days & Calendar spray \\
SIM-R-NO & Norteña & SimCast: resistant & Forecast \\
SIM-HR-NO & Norteña & SimCast: highly resistant & Forecast \\
\hline
\end{tabular}

$\mathrm{RO}$, and $0-\mathrm{NO}$ ) and a scheduled fungicide application most appropriate to the level of resistance that was set at 7 days for Alpha, 10 days for Rosita, and 14 days for Norteña, established on the basis of previous experiments (Table 1; 11). Forecasting was started on 5 July 1999 and 11 July 2000 at $50 \%$ crop emergence.

Weather data. Use of SimCast requires hourly data for rainfall, temperature, and RH. In 1999, canopy air temperature and humidity were measured with the 207probe (Campbell Scientific, Logan, UT). In 2000, canopy air temperature and humidity were measured with the Hobo logger (Onset Computer Corporation, Pocasset, MA) because the Campbell weather station and sensors were stolen in fall 1999. Temperature-RH probes were placed $0.5 \mathrm{~m}$ above soil level inside the canopy of cv. Alpha in a plot corresponding to the SimCast treatment. In both years, rainfall was measured with an automated TE525 tipping bucket rain gauge (Texas Instruments, Dallas, TX), located in a fully automated weather station approximately 20 to $100 \mathrm{~m}$ from the plots. All sensor signals were sampled at 5min intervals, and 60-min averages were calculated to enable daily forecasting. Weather data were downloaded daily to produce forecasts.

Disease estimates. Disease severity (\%) was assessed on a plot basis and was estimated visually as described previously (4). Scouting for disease was initiated at emergence of the crop, so that onset could be determined accurately. Assessments were made every 3 to 5 days starting on 3 July 1999 and 16 July 2000. Forecasts were ended following application of a vine killer (paraquat at 2 liters $\mathrm{ha}^{-1}$ ) on 9 September 1999 and 15 September 2000 for cv. Alpha and 20 September 1999 and 28 September

Table 2. SimCast blight units as determined by temperature and periods of high relative humidity $(\mathrm{RH})^{\mathrm{a}}$

\begin{tabular}{|c|c|c|c|c|c|c|c|c|c|}
\hline \multirow[b]{2}{*}{ Avg. temp $\left({ }^{\circ} \mathbf{C}\right)^{b}$} & \multirow[b]{2}{*}{ Cultivar resistance ${ }^{\mathrm{c}}$} & \multicolumn{8}{|c|}{ Consecutive hours of $\mathrm{RH} \geq 90 \%$ that should result in blight units of: } \\
\hline & & $\mathbf{0}$ & 1 & 2 & 3 & 4 & 5 & 6 & 7 \\
\hline \multirow[t]{3}{*}{$>27$} & $\mathrm{~S}$ & 24 & $\ldots$ & $\ldots$ & $\ldots$ & $\ldots$ & $\ldots$ & $\ldots$ & $\ldots$ \\
\hline & MS & 24 & $\ldots$ & $\ldots$ & $\ldots$ & $\ldots$ & $\ldots$ & $\ldots$ & $\ldots$ \\
\hline & $\mathrm{MR} / \mathrm{R} / \mathrm{HR}$ & 24 & $\ldots$ & $\ldots$ & $\ldots$ & $\ldots$ & $\ldots$ & $\ldots$ & $\ldots$ \\
\hline \multirow[t]{3}{*}{$23-27$} & $\mathrm{~S}$ & 6 & $7-9$ & $10-12$ & $13-15$ & $16-18$ & $19-24$ & $\ldots$ & $\ldots$ \\
\hline & MS & 9 & $10-18$ & $19-24$ & $\ldots$ & $\ldots$ & $\ldots$ & $\ldots$ & $\ldots$ \\
\hline & $\mathrm{MR} / \mathrm{R} / \mathrm{HR}$ & 15 & $16-24$ & $\ldots$ & $\ldots$ & $\ldots$ & $\ldots$ & $\ldots$ & $\ldots$ \\
\hline \multirow[t]{3}{*}{$13-22$} & $\mathrm{~S}$ & 6 & & $\ldots$ & $\ldots$ & $\ldots$ & $7-9$ & $10-12$ & $13-24$ \\
\hline & MS & 6 & 7 & 8 & 9 & 10 & $11-12$ & $13-24$ & $\ldots$ \\
\hline & $\mathrm{MR} / \mathrm{R} / \mathrm{HR}$ & 6 & 7 & 8 & 9 & $10-12$ & $13-24$ & $\ldots$ & $\ldots$ \\
\hline \multirow[t]{3}{*}{$8-12$} & S & 6 & 7 & $8-9$ & 10 & $11-12$ & $13-15$ & $16-24$ & $\ldots$ \\
\hline & MS & 6 & $7-9$ & $10-12$ & $13-15$ & $16-18$ & $19-24$ & $\ldots$ & $\ldots$ \\
\hline & $\mathrm{MR} / \mathrm{R} / \mathrm{HR}$ & 9 & $10-12$ & $13-15$ & $16-24$ & $\ldots$ & $\ldots$ & $\ldots$ & $\ldots$ \\
\hline \multirow[t]{3}{*}{$3-7$} & $\mathrm{~S}$ & 9 & $10-12$ & $13-15$ & $16-18$ & $19-24$ & $\ldots$ & $\ldots$ & $\ldots$ \\
\hline & MS & 12 & $13-24$ & $\ldots$ & $\ldots$ & $\ldots$ & $\ldots$ & $\ldots$ & $\ldots$ \\
\hline & MR/R/HR & 18 & $19-24$ & $\ldots$ & $\ldots$ & $\ldots$ & $\ldots$ & $\ldots$ & $\ldots$ \\
\hline \multirow[t]{3}{*}{$<3$} & $\mathrm{~S}$ & 24 & $\ldots$ & $\ldots$ & $\ldots$ & $\ldots$ & $\ldots$ & $\ldots$ & $\ldots$ \\
\hline & MS & 24 & $\ldots$ & $\ldots$ & $\ldots$ & $\ldots$ & $\ldots$ & $\ldots$ & $\ldots$ \\
\hline & $\mathrm{MR} / \mathrm{R} / \mathrm{HR}$ & 24 & $\ldots$ & $\ldots$ & $\ldots$ & $\ldots$ & $\ldots$ & $\ldots$ & $\ldots$ \\
\hline
\end{tabular}

${ }^{a}$ Blight units are estimated during a 24-h period using hourly observations starting at 1300 hours and ending at 1200 hours the following day. These rules were modified from Fry et al. (5) to work for Mexican cultivars under tropical highland conditions

${ }^{b}$ Average temperature during hours of $\mathrm{RH} \geq 90 \%$.

${ }^{\mathrm{c}}$ Level of resistance of a potato cultivar to late blight: $\mathrm{S}=$ susceptible, $\mathrm{MS}=$ moderately susceptible, $\mathrm{MR}=$ moderately resistant, $\mathrm{R}=$ resistant, $\mathrm{HR}=$ highly resistant. 
in 2000 for cvs. Rosita and Norteña, respectively.

Statistical analyses. Variables included in the data analysis were the relative area under disease progress curve (RAUDPC) and final disease severity. RAUDPC, in units of percentage days, was calculated using the midpoint method (1) and dividing the area under the disease progress curve (AUDPC) by length of the assessment period (4) to enable comparison between treatments with different assessment periods. Analyses of variance, including orthogonal contrasts (CONTRAST statement in PROC GLM), then were conducted on RAUDPCs and final disease severity (SAS
User's Guide: Statistics, SAS Institute, Cary, NC).

\section{RESULTS}

Revised SimCast. The new version of SimCast is presented in Tables 2 to 4 . Resistant and highly resistant cultivars are now included and receive the same number

Table 3. Fungicide units (for chlorothalonil) for SimCast as determined by rainfall and the number of days since the last fungicide application (Time) ${ }^{\mathrm{a}}$

\begin{tabular}{|c|c|c|c|c|c|c|c|}
\hline \multirow[b]{2}{*}{ Time (days) } & \multicolumn{7}{|c|}{ Daily rainfall amounts $(\mathrm{mm})$ that result in fungicide units of } \\
\hline & 1 & 2 & 3 & 4 & 5 & 6 & 7 \\
\hline 1 & $<1$ & $\ldots$ & $\ldots$ & $1-1.4$ & $1.5-3.4$ & $3.5-6$ & $>6$ \\
\hline 2 & $<1$ & $\ldots$ & $1-1.4$ & $1.5-4.4$ & $4.5-8$ & $>8$ & $\ldots$ \\
\hline 3 & $<1$ & $\ldots$ & $1-2.4$ & $2.5-5$ & $>5$ & $\ldots$ & $\ldots$ \\
\hline $4-5$ & $<1$ & $\ldots$ & $1-2.4$ & 2.5-8 & $>8$ & $\ldots$ & $\ldots$ \\
\hline $6-9$ & $<1$ & $\ldots$ & $1-4$ & $>4$ & $\ldots$ & $\ldots$ & $\ldots$ \\
\hline $10-14$ & $<1$ & $1-1.4$ & $1.5-8$ & $>8$ & $\ldots$ & $\ldots$ & $\ldots$ \\
\hline$>14$ & $<1$ & $1-8$ & $>8$ & $\ldots$ & $\ldots$ & $\ldots$ & $\ldots$ \\
\hline
\end{tabular}

a These rules were modified from Fry et al. (5) to work for Mexican cultivars under tropical highland conditions.

Table 4. SimCast decision rules ${ }^{\mathrm{a}}$

\begin{tabular}{|c|c|c|c|c|c|}
\hline \multirow[b]{2}{*}{ Logic statements } & \multicolumn{5}{|c|}{ Cultivar resistance $^{\mathbf{b}}$} \\
\hline & $\mathbf{S}$ & MS & MR & $\mathbf{R}$ & HR \\
\hline \multicolumn{6}{|c|}{$\begin{array}{l}\text { Fungicide should be applied if fungicide has not been applied within } 5 \\
\text { days }\end{array}$} \\
\hline AND cumulative blight units since last spray exceed: & 30 & 35 & 40 & 45 & 50 \\
\hline OR cumulative fungicide units since last spray exceed: & 15 & 20 & 25 & 30 & 35 \\
\hline
\end{tabular}

$\bar{a}$ These rules were modified from Fry et al. (5) to work for Mexican cultivars under tropical highland conditions.

${ }^{\mathrm{b}} \mathrm{S}=$ susceptible, $\mathrm{MS}=$ moderately susceptible, $\mathrm{MR}=$ moderately resistant, $\mathrm{R}=$ resistant, $\mathrm{HR}=$ highly resistant.

Table 5. Orthogonal contrasts on relative area under the disease progress curves (RAUDPC; \%-days) and final disease severity (\%) for experiments evaluating the modified SimCast ${ }^{\mathrm{a}}$

\begin{tabular}{|c|c|c|c|c|c|c|c|}
\hline \multirow[b]{2}{*}{ Orthogonal contrast $^{\mathbf{b}}$} & \multirow[b]{2}{*}{ Year } & \multicolumn{3}{|c|}{ RAUDPC } & \multicolumn{3}{|c|}{ Final disease severity } \\
\hline & & MS & $F$ value & $P>F$ & MS & $F$ value & $P>F$ \\
\hline \multicolumn{8}{|l|}{ Alpha (AL) } \\
\hline \multirow[t]{2}{*}{0 -AL vs. other ALs } & 1999 & 6,219 & 1,443 & $<0.0001$ & 29,388 & 9,263 & $<0.0001$ \\
\hline & 2000 & 3,316 & 656 & $<0.0001$ & 21,628 & 474 & $<0.0001$ \\
\hline \multirow[t]{2}{*}{ 7d-AL vs. SIM-S-AL } & 1999 & 6.7 & 1.55 & 0.2218 & 0.1 & 0.03 & 0.8593 \\
\hline & 2000 & 83.3 & 16.5 & 0.0003 & 593 & 13.0 & 0.0010 \\
\hline \multirow[t]{2}{*}{ 7d-AL vs. SIM-MS-AL } & 1999 & 0.03 & 0.01 & 0.9329 & 0.71 & 0.23 & 0.6372 \\
\hline & 2000 & 0.71 & 0.14 & 0.7113 & 1.9 & 0.04 & 0.8396 \\
\hline \multicolumn{8}{|l|}{ Rosita (RO) } \\
\hline \multirow[t]{2}{*}{0 -RO vs. other ROs } & 1999 & 15.0 & 3.48 & 0.0710 & $1,025.8$ & 323.4 & $<0.0001$ \\
\hline & 2000 & 8.7 & 1.72 & 0.1984 & 118 & 2.57 & 0.1182 \\
\hline \multirow[t]{2}{*}{ 10d-RO vs. (SIM-MR-RO \& SIM-R-RO) } & 1999 & 0.02 & 0.00 & 0.9494 & 0.15 & 0.05 & 0.8290 \\
\hline & 2000 & 0.12 & 0.02 & 0.8781 & 1.06 & 0.02 & 0.8799 \\
\hline \multirow[t]{2}{*}{ SIM-MR-RO vs. SIM-R-RO } & 1999 & 0.01 & 0.00 & 0.9545 & 0.45 & 0.14 & 0.7085 \\
\hline & 2000 & 0.00 & 0.00 & 0.9990 & 0.72 & 0.02 & 0.9009 \\
\hline \multicolumn{8}{|l|}{ Norteña (NO) } \\
\hline \multirow[t]{2}{*}{$0-\mathrm{NO}$ vs. other NOs } & 1999 & 0.76 & 0.18 & 0.6777 & 40.0 & 12.6 & 0.0012 \\
\hline & 2000 & 0.56 & 0.11 & 0.7420 & 11.4 & 0.25 & 0.6210 \\
\hline \multirow[t]{2}{*}{$14 \mathrm{D}-\mathrm{NO}$ vs. (SIM-R-NO \& SIM-HR-NO) } & 1999 & 0.00 & 0.00 & 0.9952 & 0.00 & 0.00 & 1.0000 \\
\hline & 2000 & 0.003 & 0.00 & 0.9803 & 0.18 & 0.00 & 0.9505 \\
\hline \multirow[t]{2}{*}{ SIM-R-NO vs. SIM-HR-NO } & 1999 & 0.00 & 0.00 & 0.9973 & 0.00 & 0.00 & 1.0000 \\
\hline & 2000 & 0.08 & 0.01 & 0.9037 & 1.04 & 0.02 & 0.8808 \\
\hline \multicolumn{8}{|l|}{ Level of resistance } \\
\hline \multirow[t]{2}{*}{0 -AL vs. $0-\mathrm{RO} / 0-\mathrm{NO}$} & 1999 & 5,378 & 1,248 & $<0.0001$ & 20,768 & 6,546 & $<0.0001$ \\
\hline & 2000 & 3,487 & 690 & $<0.0001$ & 24,250 & 531 & $<0.0001$ \\
\hline \multirow[t]{2}{*}{0 -RO vs. 0 -NO } & 1999 & 6.3 & 1.47 & 0.2345 & 450 & 142 & $<0.0001$ \\
\hline & 2000 & 3.7 & 0.73 & 0.3995 & 44.7 & 0.98 & 0.3300 \\
\hline
\end{tabular}

${ }^{a}$ The experiment included four replications per treatment in a randomized complete block design. A probability value $(P>F)$ significant at the 0.05 level is highlighted in bold typeface.

${ }^{\mathrm{b}}$ Fungicide treatments were as follows: cv. Alpha, $0-\mathrm{AL}=$ untreated control; 7d-AL = weekly fungicide application; $\mathrm{SIM}-\mathrm{S}-\mathrm{AL}=$ fungicide scheduling according to SimCast rules considering Alpha to be susceptible; SIM-MS-AL = fungicide scheduling according to SimCast rules considering Alpha to be moderately susceptible; cv. Rosita, $0-\mathrm{RO}=$ untreated control; $10 \mathrm{~d}-\mathrm{RO}=10$-day fungicide application; SIM-MR-RO = fungicide scheduling according to SimCast rules considering Rosita to be moderately resistant; SIM-R-RO = fungicide scheduling according to SimCast rules considering Rosita to be resistant; cv. Norteña, 0-NO = untreated control; 14d-NO = 14-day fungicide application; SIM-R-NO = fungicide scheduling according to SimCast rules considering Norteña to be resistant; SIM-HR-NO = fungicide scheduling according to SimCast rules considering Norteña to be highly resistant. 
of daily blight units as moderately resistant cultivars (Table 2). Minor changes relating to rounding of numbers are incorporated into Table 3, such that rainfall amounts can consistently be assigned to only one class of fungicide units. Major changes found in Table 4 are the inclusion of successively higher cumulative blight units or cumula- tive fungicide units for resistant and highly resistant cultivars.

Disease control. The modified version of SimCast managed disease well. In all
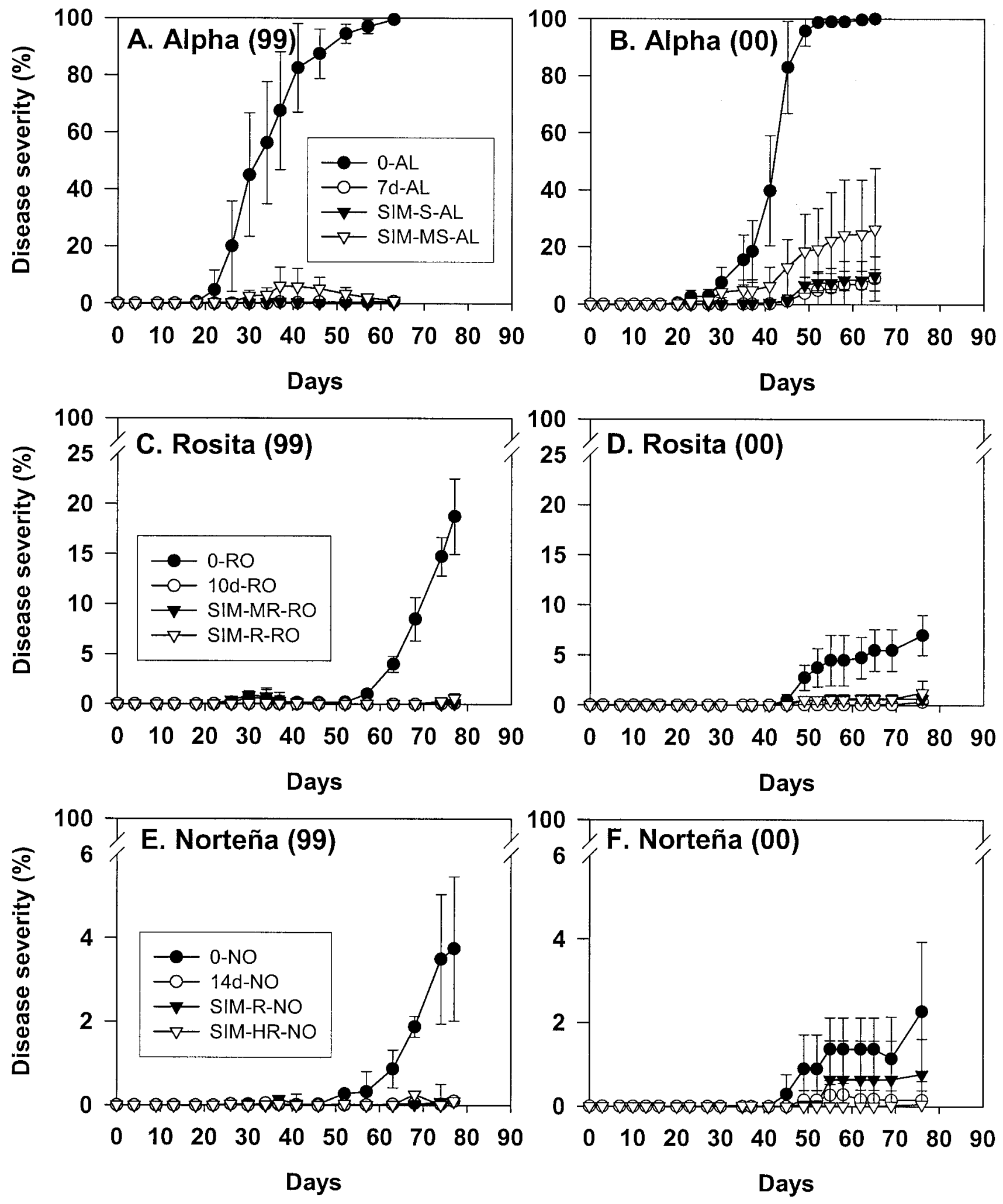

Fig. 1. Late blight disease progress curves on potato cv. Alpha (AL) in A, 1999 and B, 2000, on cv. Rosita (RO) in C, 1999 and D, 2000, and on cv. Norteña (NO) in E, 1999 and F, 2000. Treatments were an unsprayed control for each variety (0-AL, 0-RO, and 0-NO), a scheduled fungicide application every 7 days for cv. Alpha (7d-AL), every 10 days for cultivar Rosita (10-d-RO), and every 14 days for cultivar Norteña (14d-NO), and several SimCast treatments. SimCast treatments for Alpha considered Alpha to be either susceptible (SIM-S-AL) or moderately susceptible (SIM-MS-AL). SimCast treatments for Rosita considered Rosita to be either moderately resistant (SIM-MR-RO) or resistant (SIM-R-RO). SimCast treatments for Norteña considered Norteña to be either resistant (SIM-R-AL) or highly resistant (SIM-HR-AL). Shown are means and standard deviations from visual disease severity assessments, in four replicate plots, starting 3 July 1999 and 16 July 2000 when first symptoms were observed in the area. 
cases, fungicide treatments were significantly better (both in terms of RAUPDC and final disease severity) than no-spray controls (Table 5; Fig. 1). Except for the case of Alpha in 2000, all forecasting treatments gave a level of disease control equal to that of scheduled fungicide applications every 7, 10, or 14 days for cvs. Alpha, Rosita, and Norteña, respectively. When Alpha was treated as moderately susceptible using SimCast (SIM-MS-AL), disease escaped slightly in 1999 but was later controlled. In 2000, disease in the same treatment escaped significantly, ending up with $26 \%$, while disease pressure was severe because all treatments ended up with more than 9\% final disease severity (Fig. 1B).

Resistance. Disease progress was slower and level of resistance considerably higher on cvs. Rosita and Norteña compared with Alpha (Fig. 1; Table 5). In the unsprayed control treatment, both RAUDPC and final disease severity were significantly lower for Norteña and Rosita than for Alpha in both 1999 and 2000 (Table 5). Although Rosita ended up with about 5 to $20 \%$ final disease severity, Norteña ended up with 2 to $4 \%$ final disease severity (Fig. 1). Except for 1999, final disease severity and RAUPDC were not significantly different for unsprayed Norteña and Rosita (Table 5).

Number of fungicide applications. SimCast successfully forecast the appropriate number of fungicide applications required for managing late blight on the susceptible cv. Alpha. SimCast forecast 11 or 8 to 9 sprays if Alpha was considered to be either susceptible (SIM-S-AL) or moderately susceptible (SIM-MS-AL), respectively (Table 6). A weekly application (7d$\mathrm{AL})$ resulted in 10 applications.

SimCast effectively reduced the number of fungicide applications on moderate to highly resistant cvs. Rosita and Norteña compared with calendar applications. In the case of cv. Rosita, SimCast specified 6 to 7 (SIM-MR-RO) or 5 to 6 (SIM-R-RO) applications compared with 7 to 8 applications in the calendar spray treatment (10dRO) (Table 6). With cv. Norteña, the calendar spray (14d-NO) resulted in the 5 to 6 applications whereas treating Norteña as resistant in SimCast (SIM-R-NO) resulted in 5 applications. Treating Norteña as highly resistant resulted in four sprays in both 1999 and 2000 (Table 6).

Principal environmental variable responsible for spray advisories. The majority of spray advisories were made on the basis of accumulated fungicide units, which are a factor of precipitation, rather than accumulated blight units, which depend on temperature and RH (Table 6). For susceptible cv. Alpha and moderately resistant cv. Rosita, most spray advisories were made on the basis of precipitation. In the case of Norteña, three out of four (75\%) and two out of three $(67 \%)$ sprays were based on precipitation. (The first application is, by definition, based on accumulated blight units and thus is not included in the calculations). Relying exclusively on accumulated fungicide units (Table 3) and ignoring blight units (Table 2) in making spray advisories would have resulted in the same number of sprays as were actually forecast.

\section{DISCUSSION}

The modified fungicide forecasting system SimCast was successfully adapted for controlling potato late blight under tropical highland conditions in the Toluca valley. We tested the hypothesis that the modified SimCast would result in disease control corresponding to scheduled fungicide applications while reducing fungicide usage in cultivars with moderate to high levels of field resistance. SimCast resulted in good disease control on cultivars ranging from susceptible to highly resistant to potato late blight. The objective of reducing the number of fungicide applications forecast for cultivars with moderate to high levels of resistance compared with previous work (11) thus was achieved.

Table 6. Number of fungicide applications and percentage of applications forecast by accumulated fungicide units (rather than cumulative blight units) excluding the first fungicide application which is by default forecast using blight units applied for each treatment in 1999 and 2000

\begin{tabular}{|c|c|c|c|c|c|}
\hline \multirow[b]{2}{*}{ Treatment } & \multirow[b]{2}{*}{ Cultivar } & \multicolumn{2}{|c|}{ No. fungicide applications } & \multicolumn{2}{|c|}{$\begin{array}{c}\text { Percent forecasts made by } \\
\text { fungicide units }\end{array}$} \\
\hline & & 1999 & 2000 & 1999 & 2000 \\
\hline $0-\mathrm{AL}$ & Alpha & 0 & 0 & $\ldots$ & $\ldots$ \\
\hline 7d-AL & Alpha & 10 & 10 & . & $\ldots$ \\
\hline SIM-S-AL & Alpha & 11 & $12(11)^{\mathrm{a}}$ & 100 & 91 \\
\hline SIM-MS-AL & Alpha & 9 & 8 & 100 & 100 \\
\hline $0-\mathrm{RO}$ & Rosita & 0 & 0 & $\ldots$ & $\ldots$ \\
\hline 10d-RO & Rosita & 8 & 7 & $\ldots$ & $\ldots$ \\
\hline SIM-MR-RO & Rosita & 7 & 6 & 100 & 100 \\
\hline SIM-R-RO & Rosita & 6 & 5 & 100 & 100 \\
\hline $0-\mathrm{NO}$ & Norteña & 0 & 0 & $\ldots$ & $\ldots$ \\
\hline 14d-NO & Norteña & 6 & 5 & & \\
\hline SIM-R-NO & Norteña & 5 & 5 & 75 & 100 \\
\hline SIM-HR-NO & Norteña & 4 & 4 & 67 & 100 \\
\hline
\end{tabular}

${ }^{a}$ This treatment was not correctly applied, because we did not adhere to a minimum interval between sprays of 5 days as specified in Table 4 of SimCast. The correct number of applications would have been 11. A total of four applications were made 4 days after the previous application.
Interestingly, the main environmental variable responsible for making spray advisories using SimCast under tropical highland conditions in the Toluca valley was precipitation. Thus, the possibility exists of developing a spray advisory system for resource-poor farmers using inexpensive rain gauges.

One weekly application of chlorothalonil controlled disease on cv. Alpha well. This and previous work (11) indicates that Alpha should be considered susceptible. Under severe blight conditions, cvs. Rosita and Norteña should be considered to be moderately resistant and resistant, respectively, when using Table 4 of SimCast. Under moderate blight conditions, Rosita and Norteña could be considered to be resistant and highly resistant, respectively, in SimCast.

Some restrictions on the use of SimCast under Toluca Valley conditions have to be kept in mind. As with the previous version of SimCast $(5,11)$, the timing of the first application is left to the discretion of the disease management specialist. In our case, the first application was forecast using accumulated blight units (Table 2). Furthermore, SimCast was developed for use with a protectant fungicide such as chlorothalonil. Resource-poor farmers in the highland tropics use mostly the cheaper protectant fungicides, particularly mancozeb. Integration of SimCast with other fungicides with systemic or translaminar activity, such as cymoxanil, dimethomorph, propamocarb hydrochloride, and azoxystrobin, would further improve the utility of SimCast.

Our work demonstrates that a predictive system can be portable from the temperate climate to a tropical highland climate. Only minor modifications were necessary to successfully adapt SimCast to local conditions. At the same time, forecasting systems such as BLITECAST or TOMCAST were not portable to Toluca Valley conditions (11). The reason for the differences in portability might be found in the fact that SimCast incorporates both decision rules for weather effects on the pathogen as well as weather effects on the fungicide. Removal of fungicide by precipitation was the most important consideration in the success of SimCast under Toluca valley conditions. A user-friendly decision support system consisting of just a rain gauge and the exclusive use of SimCast's fungicide units (Tables 3 and 4) could be a valuable and affordable tool in managing potato late blight in the highland tropics.

\footnotetext{
ACKNOWLEDGMENTS

We thank PICTIPAPA for the use of their infrastructure; ICAMEX (Instituto de Investigación y Capacitación Agropecuaria, Acuícola y Forestal del Estado de México) for providing us with research equipment and laboratory facilities as well as conducting tractor work for our field plots; INIFAP (Instituto Nacional de Investigaciones
} 
Forestales, Agrícolas y Pecuarias) for supplying us with research equipment, providing land, and helping with tractor work; CIMMYT for their support in the importation of equipment and logistic support; W. Flier for helping out with some of the disease scoring; and M. Villaverde for supplying tubers of cv. Alpha.

\section{LITERATURE CITED}

1. Campbell, C. L., and Madden, L. V. 1990. Introduction to Plant Disease Epidemiology. John Wiley \& Sons, New York.

2. Flores-Gutiérrez, F. X. 1997. Resistencia de campo al tizón tardío Phytophthora infestans (Mont.) de Bary en variedades y clones de papa Méxicanos. Agric. Téc. Méx. 23: 15-25.

3. Flores-Gutiérrez, F. X., and Cadena-Hinojosa, M. A. 1996. Evaluation of horizontal resistance and effects of R-genes in ten Mexican cultivars against potato late blight (Phytophthora infestans) under natural conditions in the central plateau of Mexico. Rev. Mex. Fitopatol. 102:97-102.

4. Fry, W. E. 1977. Integrated control of potato late blight - effects of polygenic resistance and techniques of timing fungicide applications. Phytopathology 67:415-420.

5. Fry, W. E., Apple, A. E., and Bruhn, J. A. 1983. Evaluation of potato blight forecasts modified to incorporate host resistance and fungicide weathering. Phytopathology 73:
1054-1059.

6. Fry, W. E., and Goodwin, S. B. 1997. Reemergence of potato and tomato late blight in the United States. Plant Dis. 81:1349-1357.

7. Fry, W. E., and Goodwin, S. B. 1997. Resurgence of the Irish potato famine fungus. BioScience 47:363-371.

8. Goodwin, S. B., Spielman, L. J., Matuszak, J. M., Bergeron, S. N., and Fry, W. E. 1992. Clonal diversity and genetic differentiation of Phytophthora infestans populations in northern and central Mexico. Phytopathology 82:955-961.

9. Grünwald, N. J., Cadena Hinojosa, M., Rubio Covarrubias, O., Rivera Peña, A., Niederhauser, J. S., and Fry, W. E. 2002. Potato cultivars from the Mexican national program: Sources and durability of resistance against late blight. Phytopathology. 92:688-693.

10. Grünwald, N. J., Flier, W. G., Sturbaum, A. K., Garay-Serrano, E., van den Bosch, T. B. M., Smart, C. D., Matuszak, J. M., LozoyaSaldaña, H., Turkensteen, L. J., and Fry, W. E. 2001. Population Structure of Phytophthora infestans in the Toluca Valley Region of Central Mexico. Phytopathology 91:882-890.

11. Grünwald, N. J., Rubio-Covarrubias, O. A., and Fry, W. E. 2000. Potato late-blight management in the Toluca Valley: forecasts and resistant cultivars. Plant Dis. 84:410-416.

12. Haverkort, A. J. 1990. Ecology of potato cropping systems in relation to latitude and altitude. Agric. Syst. 32:251-272.

13. Hijmans, R. J., Forbes, G. A., and Walker, T. S. 2000. Estimating the global severity of potato late blight with GIS-linked disease forecast models. Plant Pathol. 49:697-705.

14. Rivera-Peña, A. 1990. Wild tuber-bearing species of Solanum and incidence of Phy tophthora infestans (Mont.) de Bary on the Western slopes of the volcano Nevado de Toluca. 3. Physiological races of Phy tophthora infestans. Potato Res. 33:349-355.

15. Rubio Covarrubias, O. A., Rivera Peña, A. Rangel González, J. A., Cadena Hinojosa, M. Flores López, R., Rocha Rodríguez, R., Magallanes González, J. V., Ortíz Trejo, C., Díaz Hernandez, C., López Delgado, H., Zavala Quintana, T. E., Díaz Valasis, M., and Paredes Tenorio, A. 2000. Manual para la Producción de Papa en las Sierras y Valles Altos de Centro de México. Instituto Nacional de Investigaciónes Forestales, Agrícolas y Pecuarias, Zinacantepec, Estado de México, México.

16. Tooley, P. W., Fry, W. E., and VillarealGonzalez, M. J. 1985. Isozyme characterization of sexual and asexual Phytophthora in festans populations. J. Hered. 76:431-435.

17. Walker, T. S., and Collion, M. 1997. Priority Setting at CIP for the 1998-2000 Medium-Term Plan. International Potato Center, Lima, Peru. 